- Additional material is published online only. To view, please visit the journal online (http://dx.doi.org/10.1136/ jmedgenet-2020-107595)

For numbered affiliations see end of article.

\section{Correspondence to}

Professor Judith Melki, Institut National de la Santé et de la Recherche Médicale (Inserm), UMR-1195, INSERM, Paris, Îlede-France 94276, France; judith.melki@inserm.fr

Received 16 November 2020 Revised 23 February 2021 Accepted 14 March 2021

\section{Check for updates}

(c) Author(s) (or their employer(s)) 2021. Re-use permitted under CC BY-NC. No commercial re-use. See rights and permissions. Published by BMJ.

To cite: Laquerriere $A$ Jaber D, Abiusi E, et al. $J$ Med Genet Epub ahead of print: [please include Day Month Year]. doi:10.1136/ jmedgenet-2020-107595

\title{
Phenotypic spectrum and genomics of undiagnosed arthrogryposis multiplex congenita
}

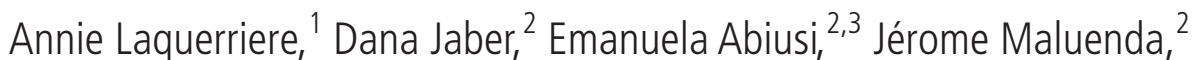

Dan Mejlachowicz, ${ }^{2}$ Alexandre Vivanti, ${ }^{2}$ Klaus Dieterich, ${ }^{4}$ Radka Stoeva, ${ }^{2,5}$ Loic Quevarec, ${ }^{2}$ Flora Nolent, ${ }^{2}$ Valerie Biancalana, ${ }^{6}$ Philippe Latour, ${ }_{1}^{7}$ Damien Sternberg ${ }_{1}^{8}$ Yline Capri, ${ }^{9}$ Alain Verloes ${ }^{9}$ Bettina Bessieres, ${ }^{10}$ Laurence Loeuillet, ${ }^{10}$ Tania Attie-Bitach, ${ }^{10}$ Jelena Martinovic, ${ }^{2,11}$ Sophie Blesson, ${ }^{12}$ Florence Petit, ${ }^{13}$ Claire Beneteau, ${ }^{14}$ Sandra Whalen, ${ }^{15}$ Florent Marguet, Jerome Bouligand, ${ }^{16}$ Delphine Héron, ${ }^{17}$ Géraldine Viot, ${ }^{18}$ Jeanne Amiel, ${ }^{19}$ Daniel Amram, ${ }^{20}$ Céline Bellesme, ${ }^{21}$ Martine Bucourt, ${ }^{22}$ Laurence Faivre $\left({ }^{2},{ }^{23}\right.$ Pierre-Simon Jouk, ${ }^{4}$ Suonavy Khung, ${ }^{24}$ Sabine Sigaudy, ${ }^{25}$ Anne-Lise Delezoide, ${ }^{24}$ Alice Goldenberg, ${ }^{26}$ Marie-Line Jacquemont, ${ }^{27}$ Laetitia Lambert, ${ }_{1}^{28}$ Valérie Layet, ${ }_{1}^{29}$ Stanislas Lyonnet, ${ }^{30}$ Arnold Munnich, ${ }^{30}$ Lionel Van Maldergem, ${ }^{31}$ Juliette Piard, ${ }^{31}$ Fabien Guimiot, ${ }^{24}$ Pierre Landrieu, ${ }^{21}$ Pascaline Letard, ${ }^{22}$ Fanny Pelluard, ${ }^{32}$ Laurence Perrin, ${ }^{9}$ Marie-Hélène Saint-Frison, ${ }^{24}$ Haluk Topaloglu, ${ }_{1}^{33}$ Laetitia Trestard, ${ }^{34}$ Catherine Vincent-Delorme, ${ }^{13}$ Helge Amthor, ${ }^{35}$ Christine Barnerias, $^{36}$ Alexandra Benachi, ${ }^{2,37}$ Eric Bieth, ${ }^{38}$ Elise Boucher (1), ${ }^{31}$ Valerie Cormier-Daire, ${ }^{19}$ Andrée Delahaye-Duriez, ${ }^{22,39}$ Isabelle Desguerre, ${ }^{36}$ Bruno Eymard ${ }^{40}$ Christine Francannet, ${ }^{41}$ Sarah Grotto, ${ }^{42}$ Didier Lacombe, ${ }^{43}$ Fanny Laffargue, ${ }^{41}$ Marine Legendre, ${ }_{4}^{43}$ Dominique Martin-Coignard, ${ }^{5}$ André Mégarbané, ${ }_{1}^{44}$ Sandra Mercier, ${ }_{1}^{14}$ Mathilde Nizon, ${ }^{14}$ Luc Rigonnot, ${ }^{45}$ Fabienne Prieur, ${ }_{1}^{46}$ Chloé Quélin, ${ }_{1}^{47}$ Hanitra Ranjatoelina-Randrianaivo, ${ }_{1}^{27}$ Nicoletta Resta $10,{ }^{48}$ Annick Toutain, ${ }^{49}$ Helene Verhelst, ${ }^{50}$ Marie Vincent, ${ }^{14}$ Estelle Colin ${ }^{51}$ Catherine Fallet-Bianco, ${ }^{52}$ Michèle Granier, ${ }^{53}$ Romulus Grigorescu, ${ }^{54}$ Julien Saada, ${ }^{37}$ Marie Gonzales, ${ }^{10}$ Anne Guiochon-Mantel, ${ }_{16}^{6}$ Jean-Louis Bessereau, ${ }^{55}$ Marcel Tawk, ${ }^{2}$ Ivo Gut, ${ }^{56}$ Cyril Gitiaux, ${ }^{57}$ Judith Melki (1) ${ }^{2,58}$

\section{ABSTRACT}

Background Arthrogryposis multiplex congenita (AMC) is characterised by congenital joint contractures in two or more body areas. AMC exhibits wide phenotypic and genetic heterogeneity. Our goals were to improve the genetic diagnosis rates of AMC, to evaluate the added value of whole exome sequencing (WES) compared with targeted exome sequencing (TES) and to identify new genes in 315 unrelated undiagnosed AMC families. Methods Several genomic approaches were used including genetic mapping of disease loci in multiplex or consanguineous families, TES then WES. Sanger sequencing was performed to identify or validate variants.

Results We achieved disease gene identification in $52.7 \%$ of AMC index patients including nine recently identified genes (CNTNAP1, MAGEL2, ADGRG6, ADCY6, GLDN, LGI4, LMOD3, UNC50 and SCN1A). Moreover, we identified pathogenic variants in ASXL3 and STAC3 expanding the phenotypes associated with these genes. The most frequent cause of $\mathrm{AMC}$ was a primary involvement of skeletal muscle (40\%) followed by brain (22\%). The most frequent mode of inheritance is autosomal recessive (66.3\% of patients). In sporadic patients born to non-consanguineous parents $(n=60)$, de novo dominant autosomal or $\mathrm{X}$ linked variants were observed in 30 of them $(50 \%)$.

Conclusion New genes recently identified in AMC represent $21 \%$ of causing genes in our cohort. A high proportion of de novo variants were observed indicating that this mechanism plays a prominent part in this developmental disease. Our data showed the added value of WES when compared with TES due to the larger clinical spectrum of some disease genes than initially described and the identification of novel genes.

\section{INTRODUCTION}

Arthrogryposis multiplex congenita (AMC) is a developmental condition characterised by joint contractures in two or more body areas resulting from reduced or absent fetal movements. AMC has an overall incidence of 1 in 3000 to $5000 .^{1}$ AMC is the direct consequence of reduced fetal movements 
which may lead, in addition to AMC, to pterygia, pulmonary hypoplasia, diaphragmatic defect or cleft palate.

There are multiple causes of AMC including (i) genetic defects, (ii) congenital infections with cytomegalovirus, varicella zoster virus, rubella virus and more recently Zika virus, (iii) extrinsic causes leading to limitations of fetal movements such as multiple pregnancy, oligohydramnios, amniotic bands or anatomical abnormalities of the uterus and (iv) maternal immune diseases such as myasthenia gravis. ${ }^{2}$

The genetic causes of AMC identified to date include a large spectrum of diseases which arise as a result of variants in genes encoding components required for the formation or the function of neuromuscular junctions, skeletal muscle, motor neurons, myelin of peripheral nerve, connective tissue of tendons and joints or central nervous system including brain with or without spinal cord anomalies. ${ }^{2}$ A total of 402 genes have been reported so far in AMC. ${ }^{3}$

There are multiple benefits for having a diagnosis and genetic evaluation for patients with AMC and their families. Indeed a specific diagnosis can precise the recurrence risks for relatives and is very helpful for the health surveillance and management required including physical therapy, orthopaedic treatment, and for the long-term prognosis.

Many AMC individuals remain without a genetic diagnosis suggesting the involvement of other pathogenic mechanisms or missed diagnosis owing to genetic heterogeneity. Our main goals were to improve the diagnosis rates of AMC, to evaluate the added value of whole exome sequencing (WES) compared with targeted exome sequencing (TES) and to identify new AMC genes. Here, we further explored genetic alterations in a cohort of 315 genetically undiagnosed and unrelated AMC families.

\section{PATIENTS AND METHODS}

\section{Patients}

A total of 315 unrelated families were included from 2011 to 2019 (online supplemental table S1). Inclusion criteria consisted of joint contractures in two or more body areas identified during pregnancy or at birth, without an unequivocal etiological diagnosis after clinical assessment by paediatricians, neuropaediatricians, fetal pathologists or clinical geneticists using targeted gene Sanger sequencing, chromosomal microarray (CMA) or molecular analysis of SMN1 (MIM: 600354) or DMPK (MIM:605377). The search for rubella or CMV infection was systematically performed. The parents of all affected individuals provided written informed consents for pathological examinations and genetic analyses of their affected children or fetuses and themselves in accordance with the ethical standards of our institutional review boards.

\section{METHODS}

\section{Genetic mapping of disease loci}

At the beginning of this study, genetic mapping of disease loci was performed in 15 multiplex and/or consanguineous families using Affymetrix GeneChip Human Mapping 250K NspI microarray. Multipoint linkage analysis of SNP data was performed using the Alohomora ${ }^{4}$ and Merlin software. ${ }^{5}$ In these families, genetic mapping was followed by either Sanger sequencing when a highly candidate gene was located within one of the disease loci $(n=7)$ or by WES $(n=8$, figure 1$)$.

\section{Targeted exome sequencing (TES)}

TES was performed on the DNA sample of affected individuals with AMC of unknown origin $(n=210$, figure 1$)$. TES was performed using the Agilent SureSelectXT Custom kit (targeting $500 \mathrm{~Kb}$ including AMC genes and candidate genes for library preparation and exome enrichment). Sequencing was performed on an Illumina MiSeq System using paired-end $150 \mathrm{bp}$ reads and following Illumina's protocol using the MiSeq Reagent Micro Kit, V.2. The median coverage was $90 \times$. Variants were selected using the same criteria as those used for WES data.

\section{Whole exome sequencing (WES)}

WES was performed from DNA of the index patient $(n=209)$. WES used the Exome Capture Agilent SureSelect XT V5 kit for library preparation and exome enrichment as previously

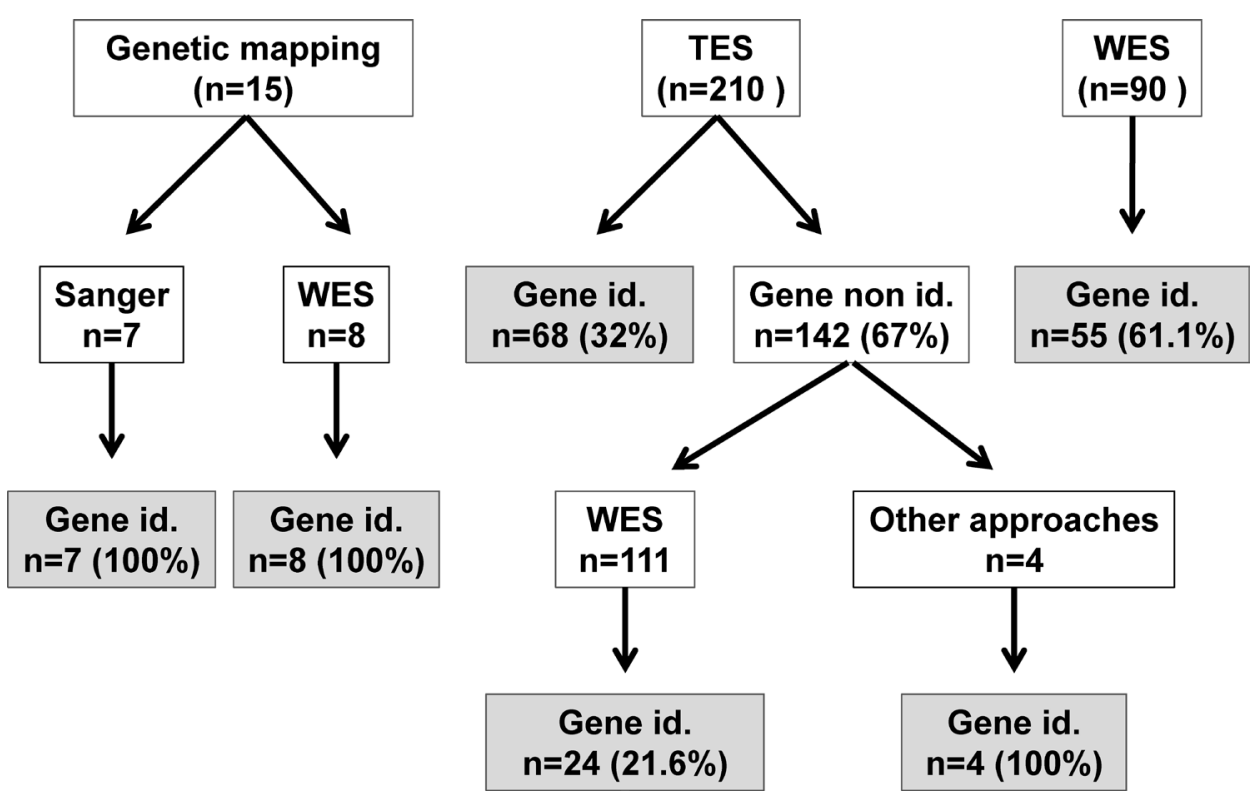

Figure 1 Genomic approaches including genetic mapping, TES or WES. n: number of unrelated patients and in brackets the percentage of index patients with disease gene identification (Gene Id.). Other approaches $(n=4)$ included CMA, SMN1, MTM1 or NIPBL analyses. TES, targeted exome sequencing; WES, whole exome sequencing. 
described $^{6}$ in 123 patients. Sequencing was performed on a Genome Analyzer IIx Illumina instrument in paired-end mode with a read length of $2 \times 100 \mathrm{bp}$. More recently, WES was performed using a completed Twist Bioscience Human Core Exome (Consensus CDS) kit for library preparation and exome enrichment in 86 patients (Integragen). Sequencing was performed on a Genome Analyzer Hiseq4000 Illumina instrument in paired-end mode with a read length of $2 \times 80$ bp (Integragen). The median coverage was $80 \times$. WES was performed either after genetic mapping of multiplex and/or consanguineous families $(n=8)$, or when the TES was negative $(n=111)$ or directly $(n=90$, figure 1$)$.

\section{Bioinformatics analysis}

Reads were aligned to the human reference genome sequence (UCSC hg19, NCBI build 37.3) via the BWA programme. ${ }^{7}$ Variants were selected using the SAMtools ${ }^{8}$ and then annotated using Annovar softwares. ${ }^{9}$ Variants in coding regions (including nonsynonymous and nonsense variants), intron-exon junctions ( $\leq 10$ $\mathrm{bp}$ ) or short coding insertions or deletions were selected when the minor allele frequency was less or equal to 0.005 (using 1000G, ExAC, TopMed and GnomAD). Prediction of pathogenicity of missense variants was performed using Polyphen-2 (with score $\geq 0.5^{10}$ ) or Sift softwares (with score $\leq 0.05^{11}$ ), splice variants using Human splicing finder ${ }^{12}$ and Clinvar (NCBI).

\section{Sanger sequencing}

Direct Sanger sequencing of candidate gene(s) located within the disease loci as established by genetic mapping was performed in seven families. Variants identified through either TES or WES were validated by Sanger sequencing. PCR amplification was carried out as previously described. ${ }^{6}$ PCR products were purified and then sequenced using the forward or reverse primers (Eurofins Genomics). The obtained DNA sequences were compared with published sequences (BLAST, NCBI). Sanger sequencing was also performed to establish the genotype of each family member and to analyse the segregation of variants within each family.

\section{Other investigations}

For recently identified genes, morphological analyses of skeletal muscle, neuromuscular junction or peripheral nerve were performed from patient samples and reported in separate reports. ${ }^{13-18}$ Functional validation of recently identified disease genes was investigated through the generation and characterisation of animal (C. elegans or Zebrafish) or cellular models and described in separate reports. ${ }^{13-18}$ When splicing mutations were identified, RNA analysis was performed to validate the pathogenic effects of mutations on RNA stability or exon splicing. Statistical analyses were performed using Fisher's exact test two tailed.

\section{RESULTS}

\section{CLINICAL DATA}

A total of 315 AMC families were included in this study from 2011 to 2019 (figures 1 and 2 and online supplemental table $\mathrm{S} 1$ ). AMC was sporadic in 226 families and familial (with at least two affected individuals) in 89 families (figure 2). In patients with sporadic AMC $(n=226), 45$ of them were born to consanguineous parents, 151 to non-consanguineous parents and unknown in 30 families. In familial AMC $(n=89)$, parents were consanguineous in 30 families, non-consanguineous in 54 and unknown in 5 (figure 2).

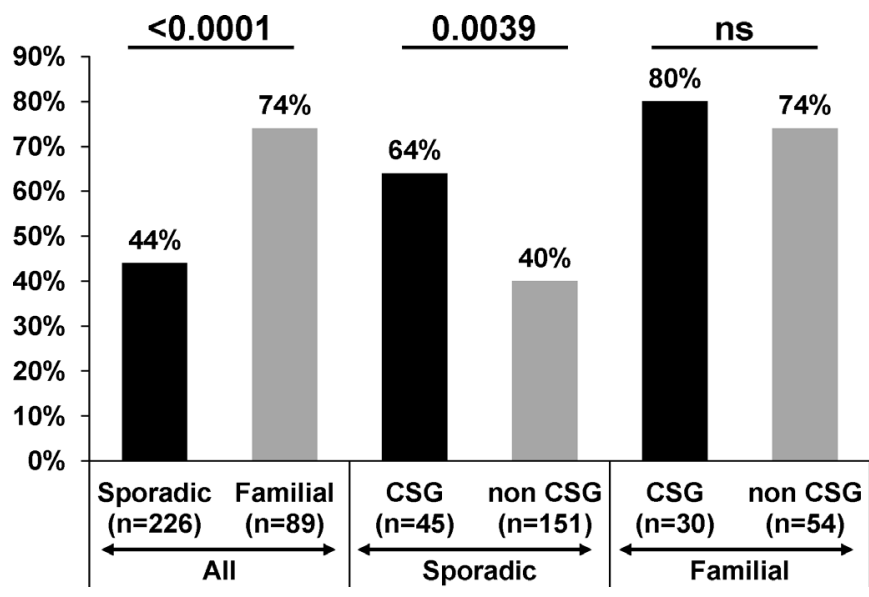

Figure 2 Comparative analysis of the percentage of patients with unrelated $A M C$ in whom the disease gene was identified depending on whether the AMC was (i) familial (at least two affected patients) or sporadic (section 'All'), (ii) in sporadic patients born to either CSG parents or not, (iii) familial AMC born to CSG parents or not. Statistical analysis was performed using Fisher's exact test two tailed. In sporadic or familial patients, the consanguinity was unknown in 30 or 5 families, respectively. AMC, arthrogryposis multiplex congenita; CSG, consanguineous; ns, not significant.

AMC was detected during pregnancy in 251 out of 315 families $(80 \%)$, after birth in 62 families $(20 \%)$ and not reported in 2 families (online supplemental table S1). During pregnancy, AMC was detected through ultrasound examination of the first trimester in 86 families (34\%), second trimester in 103 families (41\%) and third trimester in 27 families (11\%). In 35 fetuses, the exact age of discovery of AMC during pregnancy was not reported.

The AMC was classified as non-syndromic versus syndromic depending on the identification of additional features not related to the fetal akinesia sequence. A total of 213 families was classified as non-syndromic (67.6\%) and 102 as syndromic AMC (32.4\%, table 1 and online supplemental table S1). The associated features were umbilical artery anomalies $(n=3)$, brain involvement (including cognitive impairment, epilepsy, corpus callosum agenesis, perisylvian polymicrogyria, cerebellum hypoplasia, microcephaly, ventriculomegaly or macrocephaly, $n=45$ ), cardiac anomalies (such as cardiomyopathy or congenital heart defects, $\mathrm{n}=17$ ), kidney anomalies (including unilateral or bilateral pyelectasia, unilateral renal agenesis, renal hypoplasia or urolithiasis, $n=10)$, intrauterine growth retardation $(n=30)$, bone agenesis $(n=2)$, ears (such as hearing loss or unilateral ear hypoplasia, $\mathrm{n}=4$ ) or eye anomalies (microphthalmia or cataract, $\mathrm{n}=5$ ). Facial haemangioma was found in 12 affected individuals.

Among syndromic AMC $(n=102)$, both AMC and additional clinical features were discovered during pregnancy in 58 affected individuals (56.8\%). In 19 affected individuals (18.6\%), AMC and associated features were discovered after birth. Importantly, in 25 affected individuals (24.5\%), AMC was diagnosed during pregnancy but not the associated features including brain anomalies in 17 of them (online supplemental table S1).

\section{GENETIC RESULTS}

\section{Genomic strategies and results}

At the start of this study, genetic mapping of disease loci was performed in 15 families with at least two affected individuals or in sporadic affected individuals born to consanguineous 
Table 1 Summary of the main clinical features found in our cohort of 315 patients

\begin{tabular}{|c|c|c|c|c|}
\hline Main clinical features & $\begin{array}{l}\text { Total number } \\
\text { of cases }\end{array}$ & $\%$ (a) & $\begin{array}{l}\text { Number of } \\
\text { cases with } \\
\text { identified } \\
\text { gene }\end{array}$ & $\%(b)$ \\
\hline AMC & 315 & 100 & 166 & 100 \\
\hline AMC prenatal discovery & $251 / 315$ & 79.7 & $129 / 166$ & 77.7 \\
\hline AMC postnatal discovery & $62 / 315$ & 19.7 & $36 / 166$ & 21.7 \\
\hline $\begin{array}{l}\text { AMC unknown age of } \\
\text { discovery }\end{array}$ & $2 / 315$ & 0.6 & $1 / 166$ & 0.6 \\
\hline IUGR & $30 / 315$ & 9.5 & $7 / 166$ & 4.2 \\
\hline Ombilical artery anomaly & $3 / 315$ & 1.0 & $0 / 166$ & 0.0 \\
\hline Liver anomalies & $4 / 315$ & 1.3 & $1 / 166$ & 0.6 \\
\hline Eye anomalies & $5 / 315$ & 1.6 & $3 / 166$ & 1.8 \\
\hline Ear anomalies & $4 / 315$ & 1.3 & $2 / 166$ & 1.2 \\
\hline Sex anomalies & $6 / 315$ & 1.9 & $3 / 166$ & 1.8 \\
\hline Epilepsy & $9 / 146$ & 6.2 & $6 / 83$ & 7.2 \\
\hline Intellectual disability & $16 / 146$ & 11.0 & $6 / 83$ & 7.2 \\
\hline Brain malformation & $19 / 315$ & 6.0 & $4 / 166$ & 2.4 \\
\hline Bone agenesis & $2 / 315$ & 0.6 & $1 / 166$ & 0.6 \\
\hline Congenital heart defect & $14 / 315$ & 4.4 & 9/166 & 5.4 \\
\hline Cardiomyopathy & $3 / 315$ & 1.0 & $0 / 166$ & 0.0 \\
\hline Kidney anomalies & $10 / 315$ & 3.2 & $4 / 166$ & 2.4 \\
\hline Haemangioma & $12 / 146$ & 8.2 & $5 / 83$ & 6.0 \\
\hline
\end{tabular}

The percentage in (a) is the number of index patients with additional clinical features reported to the total number of AMC index patients $(n=315)$ except when the clinical features may be detected after delivery only ( $n=146)$. The percentage in (b) is the number of index patients with additional clinical features reported to the total number of AMC index patients with identified gene only $(n=166)$ except when the clinical features may be detected after delivery only $(n=83)$.

AMC, arthrogryposis multiplex congenita.

parents. When a highly candidate AMC gene was identified within a disease locus, direct Sanger sequencing of the gene was performed. Otherwise, WES was performed in the index patient. The disease gene was identified in all patients (figure 1, online supplemental table $\mathrm{S} 1$ ) including seven recently identified disease genes (ADCY6 (MIM: 600 294), CNTNAP1 (MIM: 602 346), GLDN (MIM: 608 603), LGI4 (MIM: 608 303), LMOD3 (MIM: 616 112), MAGEL2 (MIM: 605 283) and UNC50 (MIM: 617826 ), figures 1 and 3 , (online supplemental table S1). ${ }^{13-18}$

Then, targeted exome sequencing of genes known to be frequently involved in AMC or new candidate genes was performed in 210 index patients (figure 1). The first panel included 67 genes and then moved to 84 . The genetic cause was identified in only 68 affected individuals (32\%) suggesting that other genes responsible for syndromic or non-syndromic AMC were not included in the panels, or novel genes not yet identified as responsible for AMC. In the patients with undiagnosed AMC, the phenotype was first re-evaluated based on the clinical data or muscle biopsy and led to other investigations including CMA, SMN1, MTM1 (MIM: 300415) or NIPBL (MIM: 608667) analysis which allowed the identification of the disease causing gene defect in four patients (see online supplemental table S1). In 27 negative TES, other investigations including WES were not performed because of the limited DNA quantity of the index patient. When no predicted pathogenic variants were identified through TES, WES sequencing was performed in 111 index patients (figure 1). WES allowed the identification of the disease causing gene in 24 index patients (21.6\%). Among the genes identified, some of them were not included in the first TES gene panel such as BICD2 (MIM: 609797 ${ }^{19}$ ), DYNC1H1 (MIM: 600112 ${ }^{20}$ ), GBE1 (MIM: 607839 ${ }^{21}$ ), SCN4A (MIM: 60396722) and NALCN (MIM: 611549 23 ) which have been shown to be responsible for AMC since 2013. Others are genes responsible for disease for which joint contractures were not reported as the main clinical features such as ASXL3 (MIM: 615115 ${ }^{24}$ ), STAC3 (MIM: 615521 25 ), USP9X (MIM: 300072 ${ }^{26}$ ) and three recently identified genes including GLDN (MIM: 608603 ${ }^{14}$ ), LGI4 (MIM: $608303^{15}$ ) and SCN1A (MIM: $182389,{ }^{27}$ figure 3). In seven index patients, WES allowed the identification of pathogenic variants in ACTA1 (MIM: 102610), AGRN (MIM: 103320), MUSK (MIM: 601296), TPM2 (MIM: 190990), TTN (MIM: 188840) and ZC4H2 (in two patients, MIM: 300897) due to bad coverage of the variants through the TES panels (online supplemental table S1).

WES was therefore performed in the first line in 90 index patients and the disease gene was identified in 55 of them (61.1\%, figure 1). This strategy allowed us to confirm four recently identified AMC causing genes including CNTNAP1, MAGEL2, ADGRG6, SCN1A $A^{13} 172728$ or genes recently identified by other teams including TOR1AIP1 (MIM: $614512^{29}$ ) and SLC6A9 (MIM: 601019, ${ }^{30}$ online supplemental table S1 and figure 3).

Altogether, the disease gene was identified in 166 out of 315 index patients $(52.7 \%)$ and the number of disease genes found in our AMC cohort was 51 (figure 3). New genes recently identified in AMC in the last 6 years were found in 35 index patients and represent $21.1 \%$ of disease causing genes in our cohort (CNTNAP1, MAGEL2, GLDN, LMOD3, SCN1A, ADGRG6,

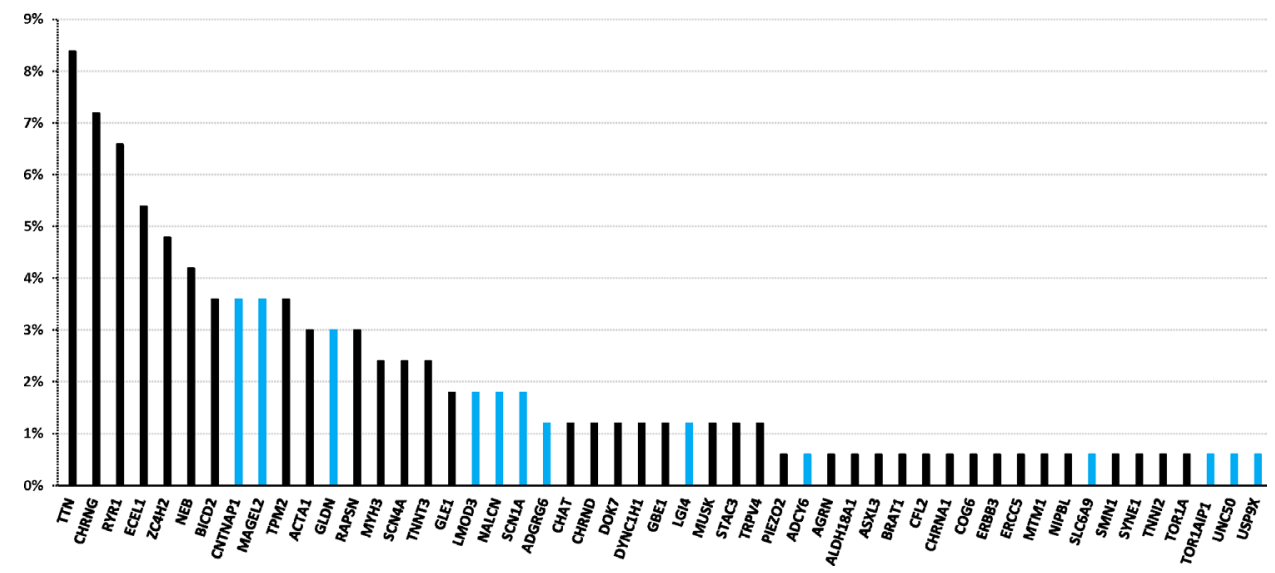

Figure 3 Genes in which pathogenic variants were identified in our cohort of AMC index patients. The percentage indicates the ratio of patients with unrelated AMC carrying pathogenic variant(s) in a given gene to 166, the total number of index patients with an identified disease gene. The blue colour indicates new genes identified in AMC within the last 6 years. AMC, arthrogryposis multiplex congenita. 


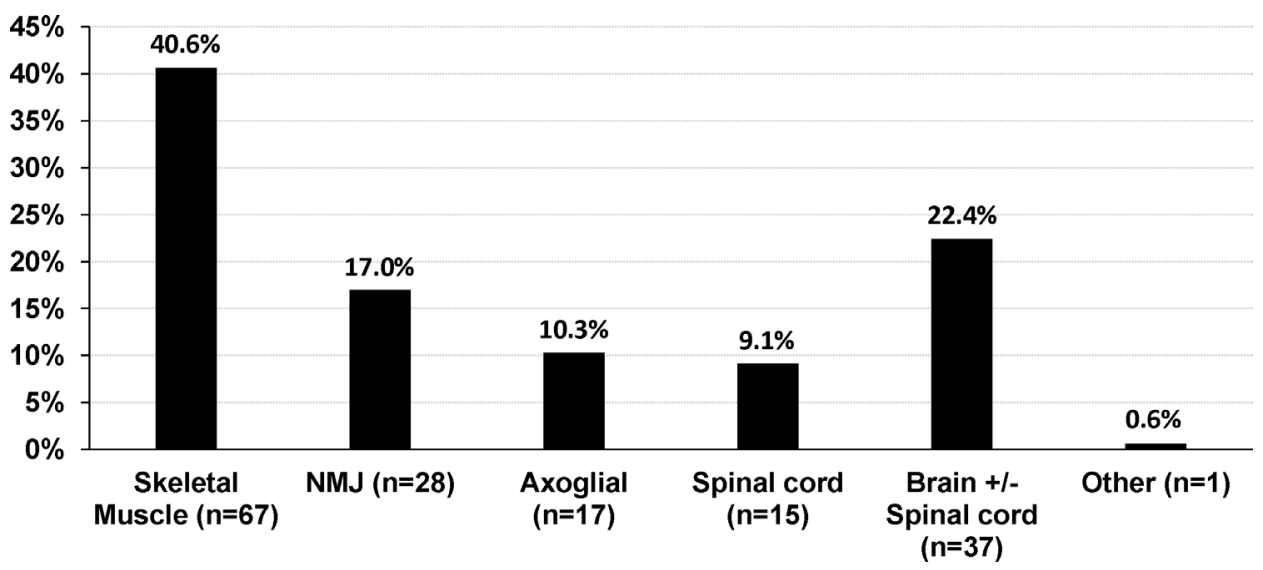

Figure 4 Pathogenic mechanisms in AMC. This study allowed an evaluation of the pathogenic mechanism through the function of the identified gene. The percentage indicates the ratio of patients carrying a mutation in a group of genes involved in a given function to 165 , the total number of index patients with an identified disease gene (without the patient carrying the chromosomal translocation). AMC, arthrogryposis multiplex congenita; NMJ, neuromuscular junction.

LGI4, UNC50, ADCY6, SLC6A9, NALCN and TOR1AIP1, figure 3$)$. In addition, we showed that pathogenic variants in ASXL3 and STAC3 might be responsible for early onset motor defect leading to AMC as the first clinical symptoms. Variants in ASXL3 were reported in Bainbridge-Ropers syndrome which is characterised by delayed psychomotor development and severe intellectual disability (MIM: $615485^{24}$ ). Variants in STAC3 are responsible for Bailey-Bloch congenital myopathy (MIM: $255995^{25}$ ) and were more recently reported in AMC. ${ }^{31}$ Variants in USP9X are known to be responsible for female-restricted $\mathrm{X}$ linked syndromic mental retardation (MIM: $300968^{26}$ ). Our data indicate a critical role of these genes in prenatal motor development leading to AMC broadening the phenotypic spectrum of variants in these genes.

Comparing the efficiency of TES with that of WES, the most efficient approach is WES $(61.1 \%$ of disease causing genes identified in affected individuals) when compared with all TES performed (32\%, figure 1).

Pathogenic mechanisms in syndromic and non-syndromic AMC This study allowed an evaluation of the pathogenic mechanism through the function of the identified gene (figure 4). The most frequent cause was a primary involvement of skeletal muscle in $40.6 \%$ of index patients $(n=67)$, brain with or without spinal cord involvement in $22.4 \%(n=37)$, neuromuscular junction in $17 \%(n=28)$, axoglial interaction in $10.3 \%(n=17)$ and spinal cord in $9.1 \%(n=15)$. The disease genes known to be associated with brain involvement including or not spinal cord and found in our cohort were ALDH18A1 (MIM: 138250), ASXL3, BICD2, BRAT1 (MIM: 614506), CNTNAP1, COG6 (MIM: 606977), ERCC5 (MIM: 133530), MAGEL2, NALCN, PIEZO2 (MIM: 613629), SCN1A, SLC6A9, TOR1A (MIM: 605204), USP9X and ZC4H2 (online supplemental table S1).

The disease causing gene was identified in 40 out of 102 patients with syndromic AMC (39.2\%) while in non-syndromic AMC $(n=213)$, the disease gene was identified in 126 patients (59.1\%, Fisher's exact test, two-tailed $\mathrm{p}=0.0011$, (online supplemental table S1). In syndromic AMC, there was no significant difference in gene identification between consanguineous (42.3\%, 11/26) and non-consanguineous AMC (41.5\%, 27/65, $\mathrm{p}=1)$. There was also no statistically significant difference in disease gene identification in patients with syndromic AMC when the phenotypic characterisation was based on prenatal data only (15 out of 47 patients, 31.9\%) when compared with the one based on postnatal findings ( 25 out of 55 patients, $45.5 \%, \mathrm{p}=0.22$ ).

Interestingly, after delivery, a total of 12 patients with AMC (12 out of 146 index patients, 8.2\%) displayed facial angioma. Among them, variants in ECEL1 (MIM: 605896), CHRNG (n=2, MIM: 100730), BICD2 and RAPSN (MIM: 601592) were found in 5 patients (online supplemental table S1). In 7 out of 12 patients with AMC with facial haemangioma, genomic analysis did not identify the gene defect. In four of them, in addition to facial haemangioma, AMC was associated with other clinical features such as mental retardation, macrosomia, cholestasis or congenital heart defect (online supplemental table S1). This data indicate that AMC associated with facial haemangioma is clinically and genetically heterogeneous including the subgroup of amyoplasia.

\section{Comparative analysis of genomic results in familial versus sporadic, consanguineous versus non-consanguineous AMC patients}

The identification of disease causing genes in 166 AMC families allowed a better evaluation of the distribution of modes of inheritance (figure 5). In 40 index patients (24.1\%), the mode of inheritance was autosomal dominant with $70 \%$ of de novo variants. It was autosomal recessive in 110 index patients $(66.3 \%)$, $\mathrm{X}$ linked in $10(6 \%)$ with a de novo variant in 6 of them and autosomal dominant with parental imprinting in 6 index patients (3.6\%) with MAGEL2 mutations with a de novo variant in 4 of them. Altogether, the percentage of de novo variants was $22.9 \%$ (38 out of 166). The most frequent mode of inheritance of AMC is autosomal recessive which represents $66.3 \%$ of diagnosed patients in our cohort.

We then compared the number of AMC families in whom the gene was either identified or not depending on whether the AMC was familial or sporadic and in sporadic patients born to consanguineous parents or not (figures 2 and 6). There was a highly statistically significant difference in gene identification in familial AMC (66 out of 89,74\%) when compared with sporadic AMC (100 out of 226, 44\%, Fisher's test, p<0.0001). In sporadic $\mathrm{AMC}$, there was also a statistically significant difference in gene identification in patients born to consanguineous parents $(29$ out of $45,64 \%)$ when compared with those born to 


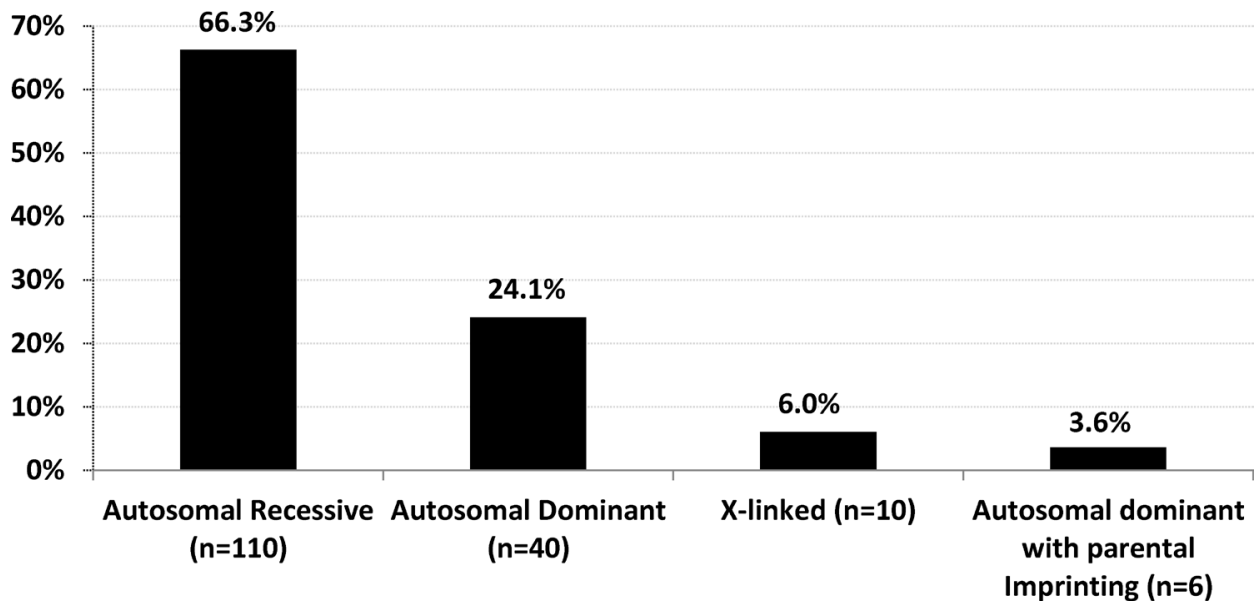

Figure 5 Modes of inheritance based on disease gene identification. The percentage indicates the ratio of patients carrying pathogenic variants ( $\mathrm{s}$ ) with a given mode of inheritance (n) to 166, the total number of index patients with an identified disease gene.

non-consanguineous parents (60 out of $151,40 \%$, Fisher's test, $\mathrm{p}=0.0039$, figure 2).

Among sporadic patients and based on gene identification, the most frequent mode of inheritance was autosomal recessive in patients born to consanguineous parents $(89.6 \%, 26$ out of 29 patients with homozygous variants in 25 of them) when compared with $43.3 \%$ (26 out of 60 ) in patients born to nonconsanguineous parents (Fisher's test, $p<0.0001$, figure 6). Importantly, de novo dominant autosomal or $\mathrm{X}$ linked variants were observed in 30 out of 60 sporadic patients born to nonconsanguineous parents (50\%) when compared with $3 \%$ in sporadic patients born to consanguineous parents ( 1 out of 29 patients, Fisher's test, $\mathrm{p}<0.0001$, figure 6). Although in 15 multiplex and/or consanguineous families, genetic mapping allowed the identification of disease loci, WES or direct Sanger sequencing detected pathogenic variants similar to those found using TES or WES only indicating that these highly statistically significant differences in gene identification in multiplex or consanguineous

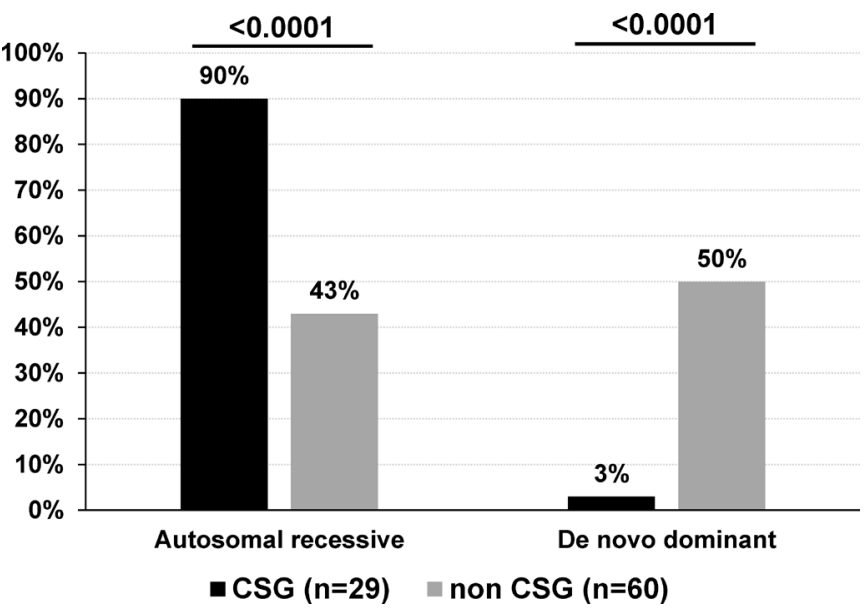

Figure 6 Modes of inheritance of sporadic patients with AMC based on disease gene identification. De novo mutations include $A D, A D$ with parental imprinting or $\mathrm{X}$ linked modes of inheritance. The percentage indicates the ratio of $A M C$ with autosomal recessive or de novo mutation to the total number of CSG ( $n=29)$ or non-CSG index patients $(n=60)$ with an identified disease gene. Statistical analysis was performed using Fisher's exact test two tailed. $A D$, autosomal dominant; $A M C$, arthrogryposis multiplex congenita; CSG, consanguineous.
AMC families compared with non-consanguineous patients with sporadic AMC are not caused by the nature or the position of the identified variant.

\section{DISCUSSION}

Pipis et al reported that in Charcot Marie Tooth disease (CMT), WES is a valuable research tool, with independent groups reporting diagnostic rates of $19 \%-45 \%$ in individuals with CMT or complex neuropathy for whom previous genetic testing was negative. ${ }^{32}$ Similarly, Ghaoui et al reported that using WES, pathogenic variants were identified in $45 \%$ of patients with limb-girdle muscular dystrophy. ${ }^{33}$ In AMC, a conclusive genetic diagnosis was established in $47 \%$ in an Australian cohort of 38 families $^{34}$ suffering from fetal akinesia/hypokinesia, arthrogryposis or severe congenital myopathies and 58.3\% including candidate genes in a Turkish cohort of 48 AMC families. ${ }^{35}$ More recently, Ravenscroft et al performed next generation sequencing in 190 probands and 81 of them received a genetic diagnosis $(42.6 \%) .{ }^{31}$ In our cohort of 315 AMC families, the largest one reported to date, our results indicate that WES is the most efficient approach with an ability of disease gene identification in $61 \%$ of AMC index patients. Our data showed indeed the added value of WES when compared with TES due to the larger clinical spectrum of some disease genes than initially described and the identification of recently published novel genes.

Indeed, this strategy allowed the identification of new AMC disease mechanisms which have been published as separate reports such as proteins involved in node of Ranvier formation (CNTNAP1, GLDN), ${ }^{13} 14$ axoglial interaction for peripheral myelination (ADCY6, ADGRG6, LGI4), ${ }^{13} 1528$ AChR trafficking (UNC50), ${ }^{18}$ organisation of sarcomeric thin filaments in skeletal muscle (LMOD3), ${ }^{16}$ brain development (MAGEL2) ${ }^{17}$ and $\mathrm{Na}^{+}$ channel function in motor cortex $(S C N 1 A){ }^{27}$ Other recently identified disease genes such as TOR1AIP $1,{ }^{29}$ SCL $6 A 9^{30}$ or $N A L C N^{23}$ were also found in our AMC cohort. Altogether, genes recently identified since 2014 in either non-syndromic or syndromic AMC were found in $21.1 \%$ of disease causing genes in our cohort. In addition, we identified pathogenic variants in ASXL $3,{ }^{24}$ STAC $3,{ }^{25}$ USP $^{2} X^{26}$ genes in patients with AMC broadening the phenotypic spectrum of variants in these genes. Variants in TTN, CHRNG, RYR1 and ECEL1 genes were found in 46 out of 166 AMC index patients in whom the disease gene was identified $(27.7 \%)$ representing therefore the most prevalent 
genetic causes of AMC (figure 3). Our results confirmed the marked genetic heterogeneity in AMC. Indeed, a total of 51 disease genes were identified in our cohort and for 21 of them, pathogenic variants were identified in a single family. New candidate genes have been recently reported in autosomal-recessive $\mathrm{AMC}^{35}{ }^{36}$ but no predicted or possibly pathogenic variants in these candidates were identified in our cohort.

In $47.3 \%$ of AMC index patients, a genetic cause was not established. Whole genome sequencing (WGS) has shown its superior diagnostic and analytical sensitivity to WES owing to its ability to assess SNVs (single nucleotide variation), indels and CNVs (copy number variation) in coding and non-coding regions and more complete per-base coverage. WGS yield has not been evaluated in AMC to date and should be proposed when the genetic cause is not established. WES or TES analysis of the index patient and not trio is likely a weakness of our approach for the detection of de novo variants in new genes. Nevertheless, the reanalysis of WES in our cohort of undiagnosed patients allowed the selection of predicted pathogenic variants in shared genes than the analysis of the intrafamilial segregation through Sanger analysis. This allowed the recent identification of de novo heterozygous variants of SCN1A in three unrelated AMC index patients. ${ }^{27}$ One hypothesis for unidentified disease causing gene would be the involvement of a digenic mechanism. However, when looking at possibly pathogenic heterozygous variant in a given gene known to be responsible for AMC, we did not observe a recurrent association with a variant in another known AMC gene. An alternative hypothesis could be the occurrence of somatic mosaicism either dominant or recessive in combination with germinal allelic variant. Further investigation including the genetic analysis of affected tissues from patients could help answer this hypothesis. Another hypothesis to explain also the marked difference between either consanguineous or familial $\mathrm{AMC}$ and sporadic $\mathrm{AMC}$ is that in numerous patients, the cause of AMC is not genetic such as possibly novel maternal immune disease(s) or viral infection such as recently described in AMC caused by Zika virus infection which might be added to rubella and CMV screening in AMC. ${ }^{37}$

Importantly, the analysis of this large cohort revealed that, based on the identified gene, the most frequent cause of AMC was a primary involvement of skeletal muscle in $40.6 \%$ of index patients $(n=67)$ followed by brain involvement with or without spinal cord defect which represents $22.4 \%$ of AMC $(n=37)$. Among syndromic AMC ( $\mathrm{n}=102)$, in 25 affected individuals, ultrasound examinations during pregnancy were normal except AMC. Among them, brain involvement was identified after birth in 17 index patients and variants in BICD2, CNTNAP1, MAGEL2, NALCN, SCN1A, SLC6A9 or ZC4H2 genes were found in 9 of them. Therefore, during pregnancy and when the AMC is observed through ultrasound examinations, the identification of the disease gene using a large gene panel or WES is critical for parent information especially when brain involvement is predicted or not through gene identification. Altogether, central nervous system involvement was observed in 44 out of 315 AMC individuals (14\%) and was characterised by either isolated or associated neurologic symptoms including, for the most frequent symptoms, epilepsy $(n=9)$, intellectual disability $(n=16)$ or brain malformations $(n=19$, online supplemental table S1).

We found that the contributions of de novo and recessive variants were quite different among consanguineous and nonconsanguineous sporadic patients with AMC based on gene identification. As expected, an autosomal-recessive inheritance is the most frequent mode of inheritance in sporadic patients born to related parents $(90 \%)$ when compared with $43 \%$ in sporadic patients born to unrelated parents. Importantly, de novo coding variants were observed in $50 \%$ of sporadic patients born to unrelated parents (when compared with $3 \%$ in patients born to related parents) and recessive coding variants in $43 \%$. Interestingly, the contribution of de novo dominant variants was quite similar in sporadic patients with AMC born to unrelated parents $(50 \%)$ to that reported in probands with European ancestry from the large Deciphering Developmental Disorders Study (DDD, $49.9 \%,{ }^{38}$ ). In the DDD study, $88 \%$ had an abnormality of the nervous system including intellectual disability or autism. Therefore, even the phenotypes of their patients were quite different from the one reported here, a similar and high proportion $(\sim 50 \%)$ of de novo variants was observed indicating that de novo dominant mutations play a prominent part in pathogenic mechanism of developmental diseases.

The benefits of an accurate genetic diagnosis include a better understanding of prognosis, more tailored management of AMC and possibly other organ involvement and improved surveillance. A precise genetic diagnosis of AMC enables an accurate genetic advice to the affected individuals and their families and may provide them with increased reproductive choice, for example, by enabling preimplantation diagnosis, non-invasive prenatal testing or prenatal diagnosis.

\section{Author affiliations}

Normandie Univ, UNIROUEN, INSERM U1245; Rouen University Hospital, Department of Pathology, Normandy Centre for Genomic and Personalized Medicine, Rouen, France

${ }^{2}$ Institut National de la Santé et de la Recherche Médicale (Inserm), UMR-1195, Université Paris Saclay, Le Kremlin-Bicetre, France

${ }^{3}$ Fondazione Policlinico Universitario A. Gemelli Istituto di Ricovero e Cura a Carattere Scientifico and Sezione di Medicina Genomica, Dipartimento di Scienze della Vita e Sanità Pubblica, Università Cattolica del Sacro Cuore, Rome, Italy ${ }^{4}$ Univ. Grenoble Alpes, Inserm, U1209, CHU Grenoble Alpes, Grenoble, France ${ }^{5}$ Department of Medical Genetics, Le Mans Hospital, Le Mans, France

${ }^{6}$ Laboratoire Diagnostic Génétique, CHRU, Strasbourg; Institut de Génétique et de Biologie Moléculaire et Cellulaire (IGBMC), INSERM U964, CNRS UMR 7104, Fédération de Médecine Translationnelle de Strasbourg, Université de Strasbourg, Illkirch, France

${ }^{7}$ Centre de Biologie Est, Hospices Civils de Lyon, Bron, France

${ }^{8}$ Service de Biochimie Métabolique et Centre de Génétique, APHP. Sorbonne

Université, GH Pitié-Salpêtrière; Centre of Research in Myology, Sorbonne University, UMRS 974, Paris, France

${ }^{9}$ Département de Génétique, Assistance publique-Hopitaux de Paris (AP-HP), Hopital Robert Debré, Paris, France

${ }^{10}$ Unité d'Embryofoetopathologie, Service d'Histologie-Embryologie-Cytogénétique, Hôpital Necker-Enfants Malades, APHP, Paris, France

${ }^{11}$ Unité d'Embryofoetopathologie, Hôpital Antoine Béclère, APHP, Clamart, France

${ }^{12}$ Service de Génétique, Unité de Génétique Clinique, CHRU de Tours, Hôpital

Bretonneau, Tours, France

${ }^{13}$ Service de Génétique Clinique Guy Fontaine, CHU Lille, Lille, France

${ }^{14}$ Service de Génétique Médicale, Centre Hospitalier Universitaire de Nantes; Institut du Thorax, INSERM, CNRS, Université de Nantes, Nantes, France

${ }^{15}$ UF de Génétique clinique et Centre de Référence Maladies Rares des Anomalies du Développement et Syndromes Malformatifs, APHP. Sorbonne Université, Hôpital Armand Trousseau, Paris, France

${ }^{16}$ Laboratoire de Génétique moléculaire, Pharmacogénétique et Hormonologie, Hôpital Bicêtre, APHP Université Paris Saclay, Le Kremlin-Bicêtre; Inserm UMR_S

1185, Faculté de médecine Paris Saclay, Université Paris Saclay, Le Kremlin-Bicêtre, France

${ }^{17}$ Département de Génétique, APHP Sorbonne Université, Hôpital Pitié-Salpêtrière et Trousseau, PARIS, France

${ }^{18}$ Unité de Génétique, Clinique de la Muette, Paris, France

${ }^{19}$ Service de Génétique Clinique, Centre de référence pour les maladies osseuses constitutionnelles APHP, Hôpital Necker-Enfants Malades; Université de Paris, UMR1163, INSERM, Institut Imagine, Paris, France

${ }^{20}$ Unité de Génétique Clinique, Centre Hospitalier Intercommunal de Créteil, Créteil, France

${ }^{21}$ Department of Pediatric Neurology, APHP-Bicêtre Hospital, Le Kremlin-Bicêtre, France

${ }^{22}$ Service d'Histologie, Embryologie, et Cytogénétique, Hôpital Jean Verdier, APHP, Bondy, France 
${ }^{23}$ Centre de Génétique et Centre de référence Anomalies du Développement et Syndromes Malformatifs, FHU TRANSLAD, Hôpital d'Enfants, CHU Dijon; UMRInserm 1231 GAD team, Génétique des Anomalies du développement, Université de Bourgogne Franche-Comté, Dijon, France

${ }^{24}$ Unité Fonctionnelle de Fœtopathologie, Hôpital Universitaire Robert Debré; Inserm UMR 1141, Paris, France

${ }^{25}$ Département de Génétique Médicale, Hôpital Timone Enfant, Marseille, France ${ }^{26}$ Department of Genetics and Reference Center for Developmental Disorders, Normandy Center for Genomic and Personalized Medicine, Normandie Univ, UNIROUEN, Inserm U1245 and Rouen University Hospital, Rouen, France

${ }^{27}$ UF de Génétique Médicale, CHU la Réunion, site GHSR, Ile de La Réunion, SaintPierre, France

${ }^{28}$ Service Génétique Clinique, CHRU Nancy, Nancy, France

${ }^{29}$ Consultations de Génétique, Groupe Hospitalier du Havre, Le Havre, France

${ }^{30}$ Imagine Institute, INSERM UMR 1163, Université de Paris; Fédération de Génétique Médicale, Assistance Publique-Hôpitaux de Paris, Hôpital Necker-Enfants Malades, Paris, France

${ }^{31}$ Centre de Génétique Humaine, Université de Franche-Comté, Besançon, France

${ }^{32}$ UMR U1053, INSERM et Université de Bordeaux; Unité de fœtopathologie, Service

de pathologie, CHU de Bordeaux, Bordeaux, France

${ }^{33}$ Yeditepe University Deparment of Pediatrics, Istanbul, Turkey

${ }^{34}$ Service de Pédiatrie, Hôpital du Belvédère, Rouen, France

${ }^{35}$ Neuromuscular Reference Centre, Pediatric Department, University Hospital

Raymond Poincaré, Garches, France

${ }^{36}$ Service de Neuropédiatrie, CR Neuromusculaire Necker, Hôpital Necker- Enfants Malades, Paris, France

${ }^{37}$ Service de Gynécologie-Obstétrique, Hôpital Antoine Béclère, AP-HP, Clamart, France

${ }^{38}$ Service de Génétique Médicale, Hopital Purpan, Toulouse, France

${ }^{39}$ Université de Paris, NeuroDiderot, Inserm, Paris, France

${ }^{40}$ Sorbonne Université, GH Pitié-Salpêtrière, Paris, France

${ }^{41}$ Service de génétique médicale et centre de référence des anomalies du

développement et des déficits intellectuels rares, CHU de Clermont-Ferrand, Clermont-Ferrand, France

${ }^{42}$ Maternité Port-Royal, AP-HP, Hôpital Cochin, Paris, France

${ }^{43}$ Service de Génétique Médicale, CHU Bordeaux, Hopital Pellegrin, Bordeaux, France

${ }^{44}$ Department of Human Genetics, Gilbert and Rose-Marie Ghagoury School of Medicine, Lebanese American University, Byblos, Lebanon

${ }^{45}$ Service de gynécologie obstétrique, Centre Hospitalier Sud Francilien, Corbei Essonnes, France

${ }^{46}$ Service de Génétique Clinique, CHU de Saint Etienne, Saint-Etienne, France

${ }^{47}$ Service de Génétique Clinique, CLAD Ouest, CHU Rennes, F-35033 RENNES, France

${ }^{48}$ Department of Biomedical Sciences and Human Oncology (DIMO), Medical

Genetics, University of Bari "Aldo Moro", Bari, Italy

${ }^{49}$ Service de Génétique, Centre Hospitalier Universitaire de Tours; UMR 1253, iBrain,

Université de Tours, Inserm, Tours, France

${ }^{50}$ Department of Pediatrics, Division of Pediatric Neurology, Ghent University

Hospital, Ghent, Belgium

${ }^{51}$ Service de Génétique Médicale, CHU d'Angers, Angers, France

${ }^{52}$ Service de Pathologie, CHU Sainte-Justine-Université de Montréal, Montréal,

Ontario, Canada

${ }^{53}$ Neonatology and Neonatal Intensive Care Unit, Centre Hospitalier Sud Francilien,

Corbeil Essonnes, France

${ }^{54}$ Unité de Génétique du Développement fœtal, Département de Génétique et Embryologie médicales, CHU Paris Est, Hôpital d'Enfants Armand-Trousseau, Paris, France

${ }^{55}$ Univ Lyon, Université Claude Bernard Lyon 1, CNRS UMR 5310, INSERM U 1217, Institut NeuroMyoGène, Lyon, France

${ }^{56}$ CNAG-CRG, Centre for Genomic Regulation (CRG), Barcelona Institute of Science and Technology (BIST); Universitat Pompeu Fabra (UPF), Barcelona, Spain

${ }^{57}$ Unité de Neurophysiologie Clinique, Centre de référence des maladies

neuromusculaires, Hôpital Necker Enfants Malades, APHP, Université de Paris, Paris, France

${ }^{58}$ Unité de Génétique Médicale, Centre de référence des anomalies du développement et syndromes malformatifs d'île-de-France, APHP, Le Kremlin Bicêtre, France

Acknowledgements We thank all families for partaking in this study. We thank the French Society of Foetal Pathology (SoFFoet) for referring clinical data and tissues of fetal patients. We thank D. Gaillard (CHU de Reims), F. Girard (CHU de Strasbourg), F. Giuliano (CHU de Nice), M. Lebrun (CHU de Saint Etienne), A. Masurel (CHU de Dijon), M. Mathieu (CHR Amiens), N. Monnier (CHU Grenoble), M. J. Perez (CHRU de Montpellier) and J. Roume (CH Poissy) for contribution and/or analysis of patient samples.

Contributors $\mathrm{AL}$ designed the study with JMe, phenotyped the patients, performed morphological analysis of the neuromuscular system and contributed to writing the manuscript. DJ, EA, JMa, DM, AVi, KD, RS, LQ, FN, VB, PLat and DS conducted molecular analyses. IG conducted WES in 123 patients. KD, YC, AVe, BB, LLa, TA-B, JMa, SB, FPet, CB, SW, FM, DH, GV, JA, DA, CB, MB, LF, P-SJ, SK, SS, A-LD, AG, M-LJ, LLo, VL, SL, AM, LVM, JP, FG, PLan, PLet, FPel, LP, M-HS-F, HT, LT, CV-D, HA, CB, AB, $E B, E B-B, V C-D, A D-D, I D, B E, C F, S G, D L, F L, M L, D M-C, A M, S M, M N, L R$, FPr, CQ, HR, $N R, A T, H V, M V, E C, C F-B, M G, R G, J S, M G, C G$ recruited and phenotyped the patients. $J-B, A G-M, V B, P L a t$ and DS validated the variants for diagnosis purpose. J-LB and MT generated and characterised animal models. JMe designed the study with $A L$, performed bioinformatics analysis of next generation sequencing data and wrote the manuscript. The authors contribute to the recruitment of patients or performed genomics analyses.

Funding This work was supported by a grant from the French Ministry of Health (PHRC 2010, AOM10181), the Association Française contre les Myopathies (AM, DAJ1891), the Agence de Biomédecine (2016), the Alliance Arthrogrypose and the Institut National de la Santé et de la Recherche Médicale (Inserm) to JMe. Several authors of the manuscript are members of the European Reference Network for Developmental Anomalies and Intellectual Disability (ERN-ITHACA).

Competing interests None declared.

Patient consent for publication Not required.

Provenance and peer review Not commissioned; externally peer reviewed.

Data availability statement All data relevant to the study are included in the article or uploaded as supplementary information. All data relevant to the study are included.

Supplemental material This content has been supplied by the author(s). It has not been vetted by BMJ Publishing Group Limited (BMJ) and may not have been peer-reviewed. Any opinions or recommendations discussed are solely those of the author(s) and are not endorsed by BMJ. BMJ disclaims all liability and responsibility arising from any reliance placed on the content. Where the content includes any translated material, BMJ does not warrant the accuracy and reliability of the translations (including but not limited to local regulations, clinical guidelines, terminology, drug names and drug dosages), and is not responsible for any error and/or omissions arising from translation and adaptation or otherwise.

Open access This is an open access article distributed in accordance with the Creative Commons Attribution Non Commercial (CC BY-NC 4.0) license, which permits others to distribute, remix, adapt, build upon this work non-commercially, and license their derivative works on different terms, provided the original work is properly cited, appropriate credit is given, any changes made indicated, and the use is non-commercial. See: http://creativecommons.org/licenses/by-nc/4.0/.

\section{ORCID iDs}

Laurence Faivre http://orcid.org/0000-0001-9770-444X

Elise Boucher http://orcid.org/0000-0002-4816-1431

Nicoletta Resta http://orcid.org/0000-0001-8640-5532

Judith Melki http://orcid.org/0000-0002-9125-3171

\section{REFERENCES}

1 Lowry RB, Sibbald B, Bedard T, Hall JG. Prevalence of multiple congenital contractures including arthrogryposis multiplex congenita in Alberta, Canada, and a strategy for classification and coding. Birth Defects Res A Clin Mol Teratol 2010;88:1057-61.

2 Hall JG. Arthrogryposis (multiple congenital contractures): diagnostic approach to etiology, classification, genetics, and general principles. Eur J Med Genet 2014;57:464-72

3 Kiefer J, Hall JG. Gene ontology analysis of arthrogryposis (multiple congenital contractures). Am J Med Genet C Semin Med Genet 2019;181:310-26.

4 Rüschendorf F, Nürnberg P. ALOHOMORA: a tool for linkage analysis using 10K SNP array data. Bioinformatics 2005;21:2123-5.

5 Abecasis GR, Cherny SS, Cookson WO, Cardon LR. Merlin--rapid analysis of dense genetic maps using sparse gene flow trees. Nat Genet 2002;30:97-101.

6 Zhou J, Tawk M, Tiziano FD, Veillet J, Bayes M, Nolent F, Garcia V, Servidei S, Bertini E, Castro-Giner F, Renda Y, Carpentier S, Andrieu-Abadie N, Gut I, Levade T, Topaloglu $\mathrm{H}, \mathrm{Melki}$ J. Spinal muscular atrophy associated with progressive myoclonic epilepsy is caused by mutations in ASAH1. Am J Hum Genet 2012;91:5-14.

7 Li H, Durbin R. Fast and accurate short read alignment with Burrows-Wheeler transform. Bioinformatics 2009:25:1754-60.

8 Li H, Handsaker B, Wysoker A, Fennell T, Ruan J, Homer N, Marth G, Abecasis G, Durbin R, 1000 Genome Project Data Processing Subgroup. The sequence alignment/map format and SAMtools. Bioinformatics 2009;25:2078-9.

9 Wang K, Li M, Hakonarson H. ANNOVAR: functional annotation of genetic variants from high-throughput sequencing data. Nucleic Acids Res 2010;38:e164.

10 Adzhubei IA, Schmidt S, Peshkin L, Ramensky VE, Gerasimova A, Bork P, Kondrashov AS, Sunyaev SR. A method and server for predicting damaging missense mutations. Nat Methods 2010;7:248-9

11 Kumar P, Henikoff S, Ng PC. Predicting the effects of coding non-synonymous variants on protein function using the SIFT algorithm. Nat Protoc 2009;4:1073-81. 
12 Desmet F-O, Hamroun D, Lalande M, Collod-Béroud G, Claustres M, Béroud C. Human splicing finder: an online bioinformatics tool to predict splicing signals. Nucleic Acids Res 2009;37:e67.

13 Laquérriere A, Maluenda J, Camus A, Fontenas L, Dieterich K, Nolent F, Zhou J, Monnier N, Latour P, Gentil D, Héron D, Desguerres I, Landrieu P, Beneteau C, Delaporte B, Bellesme C, Baumann C, Capri Y, Goldenberg A, Lyonnet S, Bonneau D, Estournet B, Quijano-Roy S, Francannet C, Odent S, Saint-Frison M-H, Sigaudy S, Figarella-Branger D, Gelot A, Mussini J-M, Lacroix C, Drouin-Garraud V, Malinge M-C, Attié-Bitach T, Bessieres B, Bonniere M, Encha-Razavi F, Beaufrère A-M, KhungSavatovsky S, Perez MJ, Vasiljevic A, Mercier S, Roume J, Trestard L, Saugier-Veber P, Cordier M-P, Layet V, Legendre M, Vigouroux-Castera A, Lunardi J, Bayes M, Jouk PS, Rigonnot L, Granier M, Sternberg D, Warszawski J, Gut I, Gonzales M, Tawk M, Melki J. Mutations in CNTNAP1 and ADCY6 are responsible for severe arthrogryposis multiplex congenita with axoglial defects. Hum Mol Genet 2014;23:2279-89.

14 Maluenda J, Manso C, Quevarec L, Vivanti A, Marguet F, Gonzales M, Guimiot F, Petit F, Toutain A, Whalen S, Grigorescu R, Coeslier AD, Gut M, Gut I, Laquerrière A, Devaux J, Melki J. Mutations in GLDN, encoding gliomedin, a critical component of the nodes of Ranvier, are responsible for lethal arthrogryposis. Am I Hum Genet 2016:99:928-33.

15 Xue S, Maluenda J, Marguet F, Shboul M, Quevarec L, Bonnard C, Ng AYJ, Tohari S, Tan TT, Kong MK, Monaghan KG, Cho MT, Siskind CE, Sampson JB, Rocha CT, Alkazaleh F, Gonzales M, Rigonnot L, Whalen S, Gut M, Gut I, Bucourt M, Venkatesh B, Laquerrière $A$, Reversade $B$, Melki J. Loss-Of-Function mutations in LGI4, a secreted ligand involved in Schwann cell myelination, are responsible for arthrogryposis multiplex congenita. Am J Hum Genet 2017;100:659-65.

16 Yuen M, Sandaradura SA, Dowling JJ, Kostyukova AS, Moroz N, Quinlan KG, Lehtokari V-L, Ravenscroft G, Todd EJ, Ceyhan-Birsoy O, Gokhin DS, Maluenda J, Lek M, Nolent F, Pappas CT, Novak SM, D'Amico A, Malfatti E, Thomas BP, Gabriel SB, Gupta N, Daly MJ, Ilkovski B, Houweling PJ, Davidson AE, Swanson LC, Brownstein CA, Gupta VA, Medne L, Shannon P, Martin N, Bick DP, Flisberg A, Holmberg E, Van den Bergh P, Lapunzina P, Waddell LB, Sloboda DD, Bertini E, Chitayat D, Telfer WR, Laquerrière A, Gregorio CC, Ottenheijm CAC, Bönnemann CG, Pelin K, Beggs AH, Hayashi YK, Romero NB, Laing NG, Nishino I, Wallgren-Pettersson C, Melki J, Fowler VM, MacArthur DG, North KN, Clarke NF. Leiomodin-3 dysfunction results in thin filament disorganization and nemaline myopathy. J Clin Invest 2014;124:4693-708.

17 Mejlachowicz D, Nolent F, Maluenda J, Ranjatoelina-Randrianaivo H, Giuliano F, Gut I, Sternberg D, Laquerrière A, Melki J. Truncating mutations of Magel2, a gene within the Prader-Willi locus, are responsible for severe arthrogryposis. Am J Hum Genet 2015;97:616-20.

18 Abiusi E, D'Alessandro M, Dieterich K, Quevarec L, Turczynski S, Valfort A-C, Mezin P, Jouk PS, Gut M, Gut I, Bessereau JL, Melki J. Biallelic mutation of UNC50, encoding a protein involved in AChR trafficking, is responsible for arthrogryposis. Hum Mol Genet 2017;26:3989-94.

19 Rossor AM, Oates EC, Salter HK, Liu Y, Murphy SM, Schule R, Gonzalez MA, Scoto M, Phadke R, Sewry CA, Houlden H, Jordanova A, Tournev I, Chamova T, Litvinenko I, Zuchner S, Herrmann DN, Blake J, Sowden JE, Acsadi G, Rodriguez ML, Menezes MP, Clarke NF, Auer Grumbach M, Bullock SL, Muntoni F, Reilly MM, North KN. Phenotypic and molecular insights into spinal muscular atrophy due to mutations in BICD2. Brain 2015;138:293-310.

20 Scoto M, Rossor AM, Harms MB, Cirak S, Calissano M, Robb S, Manzur AY, Martínez Arroyo A, Rodriguez Sanz A, Mansour S, Fallon P, Hadjikoumi I, Klein A, Yang M, De Visser M, Overweg-Plandsoen WCGT, Baas F, Taylor JP, Benatar M, Connolly AM, Al-Lozi MT, Nixon J, de Goede CGEL, Foley AR, Mcwilliam C, Pitt M, Sewry C, Phadke R, Hafezparast M, Chong WKK, Mercuri E, Baloh RH, Reilly MM, Muntoni F. Novel mutations expand the clinical spectrum of DYNC1H1-associated spinal muscular atrophy. Neurology 2015;84:668-79.

21 Ravenscroft G, Thompson EM, Todd EJ, Yau KS, Kresoje N, Sivadorai P, Friend K, Riley K, Manton ND, Blumbergs P, Fietz M, Duff RM, Davis MR, Allcock RJ, Laing NG. Whole exome sequencing in foetal akinesia expands the genotype-phenotype spectrum of GBE1 glycogen storage disease mutations. Neuromuscul Disord 2013;23:165-9.

22 Fusco C, Frattini D, Salerno GG, Canali E, Bernasconi P, Maggi L. New phenotype and neonatal onset of sodium channel myotonia in a child with a novel mutation of SCN4A gene. Brain Dev 2015;37:891-3.

23 Chong JX, McMillin MJ, Shively KM, Beck AE, Marvin CT, Armenteros JR, Buckingham KJ, Nkinsi NT, Boyle EA, Berry MN, Bocian M, Foulds N, Uzielli MLG, HaldemanEnglert C, Hennekam RCM, Kaplan P, Kline AD, Mercer CL, Nowaczyk MJM, Klein Wassink-Ruiter JS, McPherson EW, Moreno RA, Scheuerle AE, Shashi V, Stevens CA, Carey JC, Monteil A, Lory P, Tabor HK, Smith JD, Shendure J, Nickerson DA, Bamshad MJ, University of Washington Center for Mendelian Genomics. De novo mutations in NALCN cause a syndrome characterized by congenital contractures of the limbs and face, hypotonia, and developmental delay. Am J Hum Genet 2015;96:462-73.

24 Bainbridge MN, Hu H, Muzny DM, Musante L, Lupski JR, Graham BH, Chen W, Gripp KW, Jenny K, Wienker TF, Yang Y, Sutton VR, Gibbs RA, Ropers HH. De novo truncating mutations in ASXL3 are associated with a novel clinical phenotype with similarities to Bohring-Opitz syndrome. Genome Med 2013;5:11.

25 Horstick EJ, Linsley JW, Dowling JJ, Hauser MA, McDonald KK, Ashley-Koch A, SaintAmant L, Satish A, Cui WW, Zhou W, Sprague SM, Stamm DS, Powell CM, Speer MC, Franzini-Armstrong C, Hirata H, Kuwada JY. Stac3 is a component of the excitation- contraction coupling machinery and mutated in native American myopathy. Nat Commun 2013;4:1952.

26 Reijnders MRF, Zachariadis V, Latour B, Jolly L, Mancini GM, Pfundt R, Wu KM, van Ravenswaaij-Arts CMA, Veenstra-Knol HE, Anderlid B-MM, Wood SA, Cheung SW, Barnicoat A, Probst F, Magoulas P, Brooks AS, Malmgren H, Harila-Saari A, Marcelis CM, Vreeburg M, Hobson E, Sutton VR, Stark Z, Vogt J, Cooper N, Lim JY, Price S, Lai AHM, Domingo D, Reversade B, Gecz J, Gilissen C, Brunner HG, Kini U, Roepman R, Nordgren A, Kleefstra T, DDD Study. De novo loss-of-function mutations in USP9X cause a female-specific recognizable syndrome with developmental delay and congenital malformations. Am J Hum Genet 2016;98:373-81.

27 Jaber D, Gitiaux C, Blesson S, Marguet F, Buard D, Varela Salgado M, Kaminska A, Saada J, Fallet-Bianco C, Martinovic J, Laquerriere A, Melki J. De novo mutations of SCN1A are responsible for arthrogryposis broadening the SCN1A-related phenotypes. J Med Genet 2020. doi:10.1136/jmedgenet-2020-107166. [Epub ahead of print: 14 Sep 2020].

28 Ravenscroft G, Nolent F, Rajagopalan S, Meireles AM, Paavola KJ, Gaillard D, Alanio E, Buckland M, Arbuckle S, Krivanek M, Maluenda J, Pannell S, Gooding R, Ong RW, Allcock RJ, Carvalho EDF, Carvalho MDF, Kok F, Talbot WS, Melki J, Laing NG. Mutations of GPR126 are responsible for severe arthrogryposis multiplex congenita. Am J Hum Genet 2015;96:955-61.

29 Kayman-Kurekci G, Talim B, Korkusuz P, Sayar N, Sarioglu T, Oncel I, Sharafi P, Gundesli H, Balci-Hayta B, Purali N, Serdaroglu-Oflazer P, Topaloglu H, Dincer P. Mutation in TOR1AIP1 encoding LAP1B in a form of muscular dystrophy: a novel gene related to nuclear envelopathies. Neuromuscul Disord 2014;24:624-33.

30 Kurolap A, Armbruster A, Hershkovitz T, Hauf K, Mory A, Paperna T, Hannappel E, Tal G, Nijem Y, Sella E, Mahajnah M, llivitzki A, Hershkovitz D, Ekhilevitch N, Mandel H, Eulenburg V, Baris HN. Loss of glycine transporter 1 causes a subtype of glycine encephalopathy with arthrogryposis and mildly elevated cerebrospinal fluid glycine. Am J Hum Genet 2016;99:1172-80.

31 Ravenscroft G, Clayton JS, Faiz F, Sivadorai P, Milnes D, Cincotta R, Moon P, Kamien B, Edwards M, Delatycki M, Lamont PJ, Chan SH, Colley A, Ma A, Collins F, Hennington L, Zhao T, McGillivray G, Ghedia S, Chao K, O'Donnell-Luria A, Laing NG, Davis MR. Neurogenetic fetal akinesia and arthrogryposis: genetics, expanding genotype-phenotypes and functional genomics. J Med Genet 2020. doi:10.1136/ jmedgenet-2020-106901. [Epub ahead of print: 15 Oct 2020].

32 Pipis M, Rossor AM, Laura M, Reilly MM. Next-generation sequencing in CharcotMarie-Tooth disease: opportunities and challenges. Nat Rev Neurol 2019;15:644-56.

33 Ghaoui R, Cooper ST, Lek M, Jones K, Corbett A, Reddel SW, Needham M, Liang C, Waddell LB, Nicholson G, O'Grady G, Kaur S, Ong R, Davis M, Sue CM, Laing NG, North KN, MacArthur DG, Clarke NF. Use of whole-exome sequencing for diagnosis of limb-girdle muscular dystrophy: outcomes and lessons learned. JAMA Neurol 2015:72:1424-32.

34 Todd EJ, Yau KS, Ong R, Slee J, McGillivray G, Barnett CP, Haliloglu G, Talim B, Akcoren Z, Kariminejad A, Cairns A, Clarke NF, Freckmann M-L, Romero NB, Williams D, Sewry CA, Colley A, Ryan MM, Kiraly-Borri C, Sivadorai P, Allcock RJN, Beeson D, Maxwell S, Davis MR, Laing NG, Ravenscroft G. Next generation sequencing in a large cohort of patients presenting with neuromuscular disease before or at birth. Orphanet I Rare Dis 2015:10:148

35 Bayram Y, Karaca E, Coban Akdemir Z, Yilmaz EO, Tayfun GA, Aydin H, Torun D, Bozdogan ST, Gezdirici A, Isikay S, Atik MM, Gambin T, Harel T, El-Hattab AW, Charng W-L, Pehlivan D, Jhangiani SN, Muzny DM, Karaman A, Celik T, Yuregir O0, Yildirim T, Bayhan IA, Boerwinkle E, Gibbs RA, Elcioglu N, Tuysuz B, Lupski JR. Molecular etiology of arthrogryposis in multiple families of mostly Turkish origin. $J$ Clin Invest 2016;126:762-78.

36 Pehlivan D, Bayram Y, Gunes N, Coban Akdemir Z, Shukla A, Bierhals T, Tabakci B, Sahin Y, Gezdirici A, Fatih JM, Gulec EY, Yesil G, Punetha J, Ocak Z, Grochowski CM, Karaca E, Albayrak HM, Radhakrishnan P, Erdem HB, Sahin I, Yildirim T, Bayhan IA, Bursali A, Elmas M, Yuksel Z, Ozdemir O, Silan F, Yildiz O, Yesilbas O, Isikay S, Balta B, Gu S, Jhangiani SN, Doddapaneni H, Hu J, Muzny DM, Boerwinkle E, Gibbs RA, Tsiakas K, Hempel M, Girisha KM, Gul D, Posey JE, Elcioglu NH, Tuysuz B, Lupski JR, Baylor-Hopkins Center for Mendelian Genomics. The genomics of arthrogryposis, a complex trait: candidate genes and further evidence for oligogenic inheritance. Am J Hum Genet 2019;105:132-50

37 Del Campo M, Feitosa IML, Ribeiro EM, Horovitz DDG, Pessoa ALS, França GVA, García-Alix A, Doriqui MJR, Wanderley HYC, Sanseverino MVT, Neri JICF, Pina-Neto JM, Santos ES, Verçosa I, Cernach MCSP, Medeiros PFV, Kerbage SC, Silva AA, van der Linden V, Martelli CMT, Cordeiro MT, Dhalia R, Vianna FSL, Victora CG, Cavalcanti DP, Schuler-Faccini L, Zika Embryopathy Task Force-Brazilian Society of Medical Genetics ZETF-SBGM. The phenotypic spectrum of congenital Zika syndrome. Am J Med Genet A 2017:173:841-57.

38 Martin HC, Jones WD, McIntyre R, Sanchez-Andrade G, Sanderson M, Stephenson JD, Jones CP, Handsaker J, Gallone G, Bruntraeger M, McRae JF, Prigmore E, Short P, Niem M, Kaplanis J, Radford EJ, Akawi N, Balasubramanian M, Dean J, Horton R, Hulbert A, Johnson DS, Johnson K, Kumar D, Lynch SA, Mehta SG, Morton J, Parker MJ, Splitt M, Turnpenny PD, Vasudevan PC, Wright M, Bassett A, Gerety SS, Wright CF, FitzPatrick DR, Firth HV, Hurles ME, Barrett JC, Deciphering Developmental Disorders Study. Quantifying the contribution of recessive coding variation to developmental disorders. Science 2018;362:1161-4. 